\title{
Foreign Language Learning and Identity Reconstruction: Learners' Understanding of the Intersections of the Self, the Other and Power
}

Seyyed Hatam Tamimi Sa'D ${ }^{1}$

$\approx$ The present qualitative study sought to explore the relationship between English language learning and identity reconstruction from the viewpoints of Iranian language learners. The data were collected by means of focus-group interviews with forty-five male intermediate learners of English as a foreign language (EFL). To define the concept of identity, the participants were found to draw upon notions as diverse as personal and social characteristics, ethnic origins, geographical locations, religious affiliations, national customs and rituals and values, amongst others. Furthermore, the vast majority of the learners held that learning English had a profound impact on how they perceive their identity. Of these, nearly all the interviewees regarded the above impact as highly positive and beneficial to the course of language learning. The interviewees also expressed strong inclination to integrate and, therefore, to identify with the target linguistic and cultural norms. Notwithstanding, a number of opposing voices were raised by some learners who resisted identity reconstruction through language learning, claiming that they learned English simply for the sake of instrumental, as opposed to integrative, purposes. These participants also levelled criticisms at what they viewed as 'the imposition of Western values on an Islamic country'. The results highlight the vital role of motivation and the status of English as an international language in viewing, redefining and reconstructing identity. In conclusion, the findings confirm the role of discursive practices, power relations, solidarity and otherising with regard to identity reconstruction in the course of second language (L2) learning.

Keywords: English as an international language, identity reconstruction, learner identity, other, power

1 The Iran Language Institute, Iran; shtamimigo@gmail.com. 


\section{Učenje tujih jezikov in rekonstrukcija identitete: razumevanje presečišča jaza, drugega in moči}

Seyyed Hatam Tamimi Sa'd

$\propto$ Kvalitativna raziskava pojasnjuje odnos med učenjem angleškega jezika in rekonstrukcijo identitete pri iranskih učencih tujega jezika. Podatki so bili zbrani z metodo fokusnih intervjujev s petinštiridesetimi učenci nadaljevalnega tečaja učenja angleščine kot tujega jezika. Pri definiranju koncepta identitete so se udeleženci srečali z raznolikimi pojmi, med drugim na primer $\mathrm{z}$ osebnimi in družbenimi karakteristikami, etničnimi izvori, zemljepisnimi lokacijami, religioznimi pripadnostmi, nacionalnimi običaji in rituali ter $\mathrm{z}$ vrednotami. Poleg tega je velika večina učencev razumela, da ima učenje angleščine velik vpliv na način, na katerega dojemajo svojo identiteto. Od teh so skoraj vsi intervjuvanci dojeli prej omenjeni vpliv kot zelo pozitiven in koristen za tečaj učenja jezika. Intervjuvanci so izrazili tudi močno nagnjenost $\mathrm{k}$ integraciji in posledično $\mathrm{k}$ identifikaciji s ciljnim jezikovnimi in s kulturnimi normami. Čeprav je bilo zaslediti kar nekaj nasprotujočih si mnenj učencev, ki so nasprotovali rekonstrukciji identitete prek učenja jezika, sklicujoč se na to, da so se učili angleščino samo $z$ vidika instrumentalnih in ne integrativnih namenov. Ti udeleženci so prav tako enačili kritiko tistega, kar so razumeli kot »vsiljevanje vrednot Zahoda islamski državi«. Rezultati poudarjajo ključno vlogo motivacije in statusa angleščine kot internacionalnega jezika pri razumevanju, redefiniranju in pri rekonstrukciji identitete. V sklepnem delu ugotovitve potrjujejo vlogo diskurzivnih praks, odnosov moči, solidarnosti in drugega glede na rekonstrukcijo identitete v okviru tečaja učenja drugega jezika.

Ključne besede: angleščina kot internacionalni jezik, rekonstrukcija identitete, identiteta učenca, drugi, moč 


\section{Introduction}

Learning a new language is an overarching experience that involves the whole person: physically, cognitively, and emotionally. In this experience, language learners fluctuate between an understanding of themselves as speakers of their first language (L1) and their awareness of themselves as learners of a second language (L2), of how they 'identify' themselves. Hence, it is believed that identity construction through language use is an ongoing, continuous, and dynamic process (Larsen-Freeman \& Cameron, 2007).

Furthermore, language is assumed to be central to human cognition and condition, identity construction and self-development (Edwards, 2009). Norton (1997) argued that language both shapes and is shaped by one's identity. In addition, it is commonly acknowledged that language learning and identity reconstruction are closely linked (Edwards, 2009; Johnson \& Johnson, 1999; Norton, 1995, 1997, 2009) although discussions of identity theory seldom fall directly under the rubric of research in second language acquisition (SLA) (Ortega, 2009).

The present study attempts to demonstrate language learners' understanding of the impact of learning English on their identity perception, reconstruction and redefinition based on qualitative data generated by means of focus group interviews (see Appendix). The results are discussed within the broader global context and status of English and references are made to the power relationships inherent in the course of learning English in a non-Western, EFL context (i.e., Iran).

\section{Identity}

Identity is based on both similarity and difference. Individuals identify with that to which they find themselves similar; conversely, they often dissociate with and feel apprehensive about what they regard as different or conflicting. Edwards (2009) remarked that the underlying construct of identity is similarity, basing such theorising upon the Latin root of the word 'identity'(identitas), which means 'same'. Two decades ago, Norton (1997), the leading figure in research on identity in language, strongly defended the heated discussion on the relation between language learning and identity, viewing it as intimately tied to language education theorising. In this regard, Norton argued that language learners are constantly engaged in a continuous process of identity construction every time they speak. However, according to van Lier (as cited in Deters, 2011), research on identity and its relationship with language and agency is in its 
infancy. It is maintained that speakers can also demonstrate their identity in an L2 through their L1. For instance, Kasper (as cited in Johnson \& Johnson, 1999) and Tamimi Sa'd and Modirkhamene (2015) observed that language learners preserve their L1 norms, for example, their L1-accented speech, not as a sign of negative pragmatic transfer but to mark their identity.

Theorising identity has produced several theories of identity. Furthermore, various categories and types of identity have been mentioned in the literature including 'social identity', 'sociocultural identity', 'cultural identity', 'ethnic identity', amongst others (Norton, 1997). In this line of research, identity has been approached from various perspectives. One approach to identity is poststructuralist which, according to Norton (2013, 2014), attempts to explain identity in terms of our subjectivity defined simply as 'our sense of ourselves' (p. 4). Subjectivity is explained in terms of power; that is to say, individuals are either subjects of power or subjects to power. Accordingly, power is a key notion in research on identity (see Morita, 2004). Indeed, studies that explore perceptions of identity reconstruction through target language (TL) learning are likely to reveal interesting insights, which will, in turn, cast light on the possible paths that learners tread to acquire a new language and, most probably, a new identity and self.

\section{Theoretical background}

A growing mass of evidence from a variety of disciplines has demonstrated that language learning and identity (re)construction are closely associated. This issue has received considerable research attention from many researchers (see, e.g., Barnawi, 2009; Huang, 2011; Joseph, 2009; Lazzaro-Salazar, 2013; Nabavi, 2010; Norton, 1995, 1997, 2009, 2011; Norton \& McKinney, 2011; Roth, 2010). Many scholars even regard language learning and identity as inseparable (Day, 2002; Edwards, 2009; Norton, 1997). Norton (2011) believes that the recent burgeoning interest in identity comes as a result of a shift of interest from the psycholinguistic aspects of language learning to an emphasis on the sociological and anthropological dimensions of language acquisition. In a review of the literature on identity and education since the 1970s, Norton (2011) traced the development of research on this concept in light of such notions as resistance, imagined communities, and investment. Summarising her review thus, she explains, 'the extent to which a learner speaks or is silent, and writes, reads, or resists has much to do with the extent to which the learner is valued in any given institution or community' (p. 326). In addition to Norton, other researchers have also been concerned with how power and resistance affect identity (e.g., Burr, 2006; Sato, 2014; 
Schecter \& Bayley, 1997; Trappes-Lomax, 2004; Wang \& Phillion, 2011). In another recent study, Barnawi (2009) examined the identity negotiation and shaping of two Saudi Arabian students of English at American universities. Barnawi's study focused on the subjects' competence in participation and membership and revealed their difficulty socialising in the TL community.

Taking a metaphor approach, Huang (2011) set out to examine identity development by 35 Taiwanese students of non-English majors. The results confirmed that the majority of the participants reported positive metaphors to describe their L2 self-development through learning English. Zacharias (2012) studied 35 Indonesian multilingual EFL learners' identity negotiation and construction. This study demonstrated that the participants rated their national identity negatively. Zacharias further argued that this negative view resulted from the participants' recognition of themselves as non-native speakers (NNSs) and, therefore, as linguistically incompetent compared to native speakers (NSs). Morita (2004) also conducted a multiple case study on L2 learners' negotiation of identities and participation in a Canadian university to determine that relations of power played a significant role in this process. Similarly, Wang and Phillion (2011) examined the identity construction of two Hui students in eastern China based on the postcolonial theory of identity. Their analysis revealed that Hui students' identity construction was related to issues of power, dominance, and hegemony. In another study which used interviews as the data collection tools, Li and Simpson (2013) investigated migrant learners' attitudes of English to Speakers of Other Languages (ESOL) toward identity reconstruction in a migrant context. Taking a poststructuralist perspective of identity, Li and Simpson (2013) assert that understanding the process of identity reconstruction can assist us in gaining a better insight into needs analysis.

More recently, using data gathered by means of questionnaires and interviews, Lefkowitz and Hedgcock (2006) demonstrated how Spanish learners of English negotiated their identity in English through adopting standard pronunciation due to social pressure. Most recently, Sato (2014) carried out a study of the effect of study abroad on Japanese students' identity construction. In line with Wang and Phillion (2011), Sato's findings demonstrated that equitable power relations contributed to favourable L2 identity construction, as did Wortham's (2010) study of Tyisha, a black girl, and her identity development in classroom settings. Similarly, Kinginger (2004) tracked four years in the life of Alice, a motivated learner of French, narrating her story throughout her language learning journey. Ritzau (2015) carried out a study that clearly demonstrated that students of Danish, even at a beginning level of language learning, embarked on self-positioning and identity work in the TL. Despite 
the significance of L2 identity perception and negotiation, research on learners' perceptions of identity reconstruction through language learning in the Iranian context has not been very rigorous. The findings of the study will hopefully be concerned with critical pedagogy, needs analysis and teacher education programs. The objective of the current study is three-fold: a) to explore how Iranian language learners define, perceive and conceptualise identity; b) to evaluate language learners' perceptions of their identity as Iranians (i.e., national identity); and c) to appraise the way Iranian language learners interpret L2 identity reconstruction. Therefore, the following research questions are put forward:

1. How do Iranian EFL learners perceive and define identity?

2. How do Iranian EFL learners assess their national identity (i.e., as Iranians)?

3. How do Iranian EFL learners perceive identity reconstruction through learning English?

\section{Methodology}

\section{Participants and Setting}

Forty-five intermediate learners of English as a Foreign Language (EFL) participated in the current study. All the participants studied English at the same private language institute in Ahwaz, Iran and constituted males only. Their age range was within 13-21, and their English learning experience ranged from 1 to 6 years. In terms of ethnic as well as linguistic background, the participants constituted Arabs, Turks and Persians and spoke Arabic, Turkish and Persian as their mother tongues. The selection procedure was convenience sampling, that is, a sampling method in which those participants who are available for the study are selected (Mackey \& Gass, 2005).

\section{Instruments}

The data were elicited by means of focus-group interviews. These interviews comprised eight questions which enquired about diverse issues surrounding identity including the definition of identity, the importance of identity, the effect of foreign language learning on one's identity and learners' attitudes toward identity reconstruction through language learning (if any). The participants were asked to elaborate on these issues whenever possible during the interviews. It is noteworthy that the focus-group interviews were conducted in Persian to ensure the interviewees' full comprehension of the questions. 


\section{Procedure and Data Analysis}

The present study is qualitative, with data collected by means of focusgroup interviews which were tape-recorded to be analysed later. The collected data were analysed in search of recurring themes and emergent categories arising from the interview transcripts. As stated before, the interviews were carried out in Persian and the interview transcripts that appear in this study are their English translations.

\section{Results}

The objective of the study was three-fold: to examine the way Iranian learners of English define and view identity, to evaluate the participants' understanding of the possible impact of learning English on their identity, and finally to assess their attitudes toward such an impact as well as the major factors that cause it.

\section{Identity: Definitions}

The participants' definition of identity was the first question addressed in the interviews. The participants were simply required to offer their definition of 'identity' and what they perceived as composing identity (Question \#1). Some definitions are as follows:

Interviewee 1. A person's identity shows what sex, language and race that person has.

Interviewee 6. In my opinion, identity refers to what type a person one is, as well as to his/her culture, language, etc. It is also part of their behaviour and abilities.

Interviewee 8. Everyone's identity shows that person's existence. It also depends on his/her race.

Interviewee 21. Identity means your nationality and culture.

Interviewee 22. Identity is what we do.

Interviewee 28. Identity is our actions and behaviours. It is our norms and values.

Interviewee 31. Identity means one's existence. It is how one lives and the characteristics he has. Identity varies with one's geographical location and place of living.

Interviewee 36. I believe that one's identity shows his/her whole life. It shows how a person lives, speaks, behaves, etc. 
Interviewee 38. I think my identity is my nationality, personality, ethnicity, and religion.

Interviewee 42. Identity is what defines a human being and determines what type of person one is like whether he is Muslim, Arab, etc.

The analysis of the definitions of identity that the participants provided indicates that the following themes emerge as the building blocks and constituents of identity:

- Geographical boundaries: place of birth, residence, and work

- $\quad$ Nationality: national values, customs, rites, and ceremonies

- Culture: cultural and social values, norms, and standards

- $\quad$ Personality: personal values, morals, manners, beliefs, and worldviews

- $\quad$ Religion: religious values, beliefs, rituals, and acts

- Ethnicity, race and ancestry: ethnic origins, racial background, and ancestral traditions

- $\quad$ Sex: sexual features, characteristics, and capabilities

- Existence: one's mere existence in the world

- Physical body: bodily features and characteristics

- Family and relations: people, communication, and relations

- Civilisation: historical background and backdrop

- Behaviour: one's actions, behavioural manifestations, and patterns

The above markers of identity are remarkably diverse, ranging from personal to social to individual and biological features. These definitions are highly illuminating, clearly demonstrating that the interviewees perceive identity as being both personally and socially constructed; that is, identity should be defined in both personal and social terms. This demonstrates the highly different, and at times conflicting, perceptions with which the participants have proceeded to define and mark the notion of identity.

These definitions are wide-ranging and have been accurately reflected in the relevant scholarly literature. Identity has been defined on two levels: personal and social (Edwards, 2009). The personal level characterises individual characteristics, features and traits. At the social level, identity is carried through history and tradition. Roth (2010) defines identity simply as 'who someone is' (p. 155), speculating that it includes issues and matters as diverse as motivation, interests, attitudes, locus of control, aspirations, perceptions, and the likes (p. 115). The interviewees' definitions demonstrate that they conceive of identity as being a multi-layered, many-sided notion. This finding is in line with the scholarly literature which conceptualises and situates identity in terms of 
ethnicity (Davies, 2007; Johnson \& Johnson, 1999), nationalism (Davies, 2007; Edwards, 2009; Johnson \& Johnson, 1999; Saville-Troike, 2006), gender and sex (Johnstone, 2008), linguistic background (Davies, 2007; Johnson \& Johnson, 1999), family and relations (Johnson \& Johnson, 1999) and religious values and rituals (Rich \& Troudi, 2006). Johnstone (2008) maintains that most research attention has been directed toward ethnicity, gender, nationality and race as the significant factors with which social identities are associated. She further explicates that identity can be defined in terms of one's performance, a view which is humanistic, rhetorical, and deterministic. According to Johnstone, such a view highlights responsibility for one's actions. With regard to the personal side of identity, Johnstone (2008) states, 'Current ways of understanding social identity and its relationship to discourse are rooted in the idea that the selves we present to others are changeable, strategic, and jointly constructed' (p. 155). Therefore, the personal is found to be complemented by the social. This mutual interconnection will, in turn, account for the major part of the diversity in defining identity by the learners. Linguistically, identity might be expressed through one's mother tongue accent in the TL, as well (Tamimi Sa'd \& Modirkhamene, 2015).

The complex web of variables and components in which the interviewees defined identity can be accounted for by regarding this diversity as socially purposeful. According to Johnstone (2008), defining identity on the basis of such diverse factors and variables serves the purpose of 'categorisation'. Speakers tend to 'categorise' others into groups based on their linguistic background, nationality, and so on. Part of the multi-layered and multifaceted nature of identity is understandable, particularly due to and since the introduction of what has been called 'postmodernism', which regards identity not as a fixed and stable concept but as a complex, dynamic and changing phenomenon continuously and constantly constructed and reconstructed though diverse discourses and practices (Deters, 2011). Prior to that, Norton (1997) articulated a similar view of identity by arguing in favour of a contradictory, complex and multifaceted definition. Recently, Larsen-Freeman and Cameron (2007) have also adopted a similar approach to language called 'complexity theory' or 'complex systems theory', which views language as a complex, adaptive and dynamic system, constantly in a state of flux and change. A key point to make here is the fact that some of the constituents of identity numerated above are relatively fixed (e.g., geography, sex, etc.) while others are more flexible (e.g., behaviour, culture, etc.). This distinction between these types of factors leads to the conclusion that while human agency might not be at play in the case of the former set of factors, it is at work in the latter set (Kabuto, 2011). In fact, as Kabuto (2011) 
argued, 'At the same time, identities are multiple. We can have different types of "selves" that make up who we are: a teacher, a mother, a wife, and a friend [...]' (p. 20). The numerous components referred to in the interviewees' definitions of identity indicate that the interviewees see themselves as capable of enacting various multi-faceted and changing identities (see Ebtekar, 2012).

\section{Identity: Importance}

The next question concerned itself with the significance of having and identifying oneself with a specific identity and the reason(s) for that significance or the lack thereof (Question \#2). The responses to this question reveal that 24 interviewees (53\%) believed that it is highly important for one to associate oneself with a special identity, while 21 (57\%) interviewees did not consider this to be of much significance. Some of the quotes follow below:

Interviewee 14. Everyone has an identity which shows his/her behaviour and race. Identity is important because foreigners ask you about it.

Interviewee 17. Identity is very important because everyone behaves according to his/her identity and this behaviour will be different for different people.

Interviewee 19. Having a special identity shows the value of our nation and shows how we appreciate our nation.

Interviewee 23. Identity is very important because people with different identities have different ways of living and patterns of behaviour. Therefore, they communicate in different ways, too.

Interviewee 28. Yes, it's important to have a specific identity because people are different because they have distinct identities. It'll not make sense to speak of identity if all people have the same identity.

From the above quotes, it is seen that the participants defined identity not only in terms of the components mentioned in Section 1 (e.g., nationality, race, ethnicity, behaviour, etc.) but also conceived of it as comprising these factors. In fact, it is argued that identity is important merely because of what it consists. Simply put, identity is of importance in and of itself. However, some respondents regarded identity as unimportant. Consider the following quotes:

Interviewee 11. Identity isn't that important to me because what I want to know is the other person's nationality.

Interviewee 16. It's not important at all because all people have similar rights and responsibilities.

Interviewee 19. It's hardly important to have a special identity. What 
counts is your talents and abilities.

Interviewee 22. Humans are humans whether he comes from Iran or anywhere else.

Interviewee 41. Identity is not important because the colour of your skin doesn't change the way you think!

Despite all the above and next quotes which indicate that a large variety of factors are at work to form identity, some participants contend that identity is not formed by these factors and view it as separate. One participant, for instance, said:

Interviewee 32. A person's identity isn't very important; instead, what one does and cares about is that person's personality and behaviour.

\section{National Identity}

Identity is closely associated with one's nationality, national values and customs and nationally shared beliefs (Edwards, 2009; Johnson \& Johnson, 1999; Saville-Troike, 2006). In this regard, national borders define what identity is and how it is to be constructed and maintained. In light of this issue, the next interview question was concerned with how the participants regarded themselves as Iranian before they embarked on learning English (Question \#4). Some responses are as follows:

Interviewee 3. As a kid I didn't use to like English but once I started to study it I learned that English is an international language.

Interviewee 7. Before I started to learn English, I didn't care about English or English-speaking countries. I had a world as small as Iran. At that time, I thought my identity was complete but after I started to study English I understood that there was a long way for me to take.

Interviewee 36. I think I was an ordinary Iranian before I started to learn English.

Interviewee 38. I've felt more complete since I started to learn English and because of this I've become more interested in learning English. Like Persian, this language is interesting to me.

Interviewee 44. I used to view myself as superior to others.

The analysis of the above quotes and many others reveals that the international status of English impacts the way learners from the 'expanding circle' of English view this language. Several participants explicitly stated that they learn English because of the prestige that comes from this internationally 
spoken language. The above interview transcripts are in line with the major aim of identity theory which is said to be the integration of the individual language learner and the social world (Norton, 2011). Arguably, invoking nationality and investing in it as a major component in defining identity might be the participants' strategy to seek recourse in the attempt to preserve for themselves the rights of citizenship (Nabavi, 2010).

\section{Identity Reconstruction through English}

The interviewees were next asked to state whether and in what way the learning of English and exposure to this language has had any effect on their identity (Question \#3). Furthermore, they were required to state whether they viewed this effect as positive or negative. The results were as follows: of the total 45 participants, 33 held that learning English has impacted the way they view their identity. Of these, 26 participants deemed this impact as positive, 5 participants as negative and two others as both positive and negative. In contrast, 12 interviewees maintained that learning English did not have any effect on their identity perception. The following quotes were articulated in response to the inquiry regarding the effect of learning English on one's identity:

Interviewee 1. It [the effect of learning English] has been positive because it enabled me to get familiar with other cultures.

Interviewee 8. Learning English caused me to shape a positive attitude toward it because I'll use English a lot in the future since it's an international language.

Interviewee 11. If we get an English identity when we learn English, we can get much information about English culture.

Interviewee 15. We can increase our knowledge and value by learning another language whether it is Arabic, English, or Turkish. In this way, we can communicate more with others.

Interviewee 27. By learning English, we can get to know English-speaking people and their identity better.

The participants were next questioned regarding their beliefs about their current views of identity in the L2 after having been exposed to the experience of learning English (Question \#4). Some of the responses that this question drew are as follows:

Interviewee 2. Learning English caused me to try to understand the meaning of English texts first by grasping their 'English' meaning instead of looking at their Persian translation. 
Interviewee 5. After I started to learn English I came to understand that I still needed to do a lot of practice and make more effort in order 'to complete my identity'.

Interviewee 24. I haven't changed too much but by using English now I can get useful information about other people and correct some of the 'bad' habits of my own culture.

Interviewee 35. I've started to think that I'm getting a new identity and that I can get what I want now.

Interviewee 41. My view has improved because when I started to study English I was very enthusiastic to get to know other cultures and now I think it's OK if those cultures become part of my identity.

Interviewee 45. Since I started to learn English I've learned that I belong to an outdated society and culture.

Of relevance here is Norton's Social Identity Theory (Norton, 1997, 2011). Norton (1997) defined Social Identity as 'the relationship between the individual and the larger social world, as mediated through institutions such as families, schools, workplaces, social services, and law courts' (p. 420). Norton's theory examines and challenges the notion of power, attempting to demonstrate how language learners can create ample opportunity for language learning by challenging the dominant power relations. However, despite the above quotes, some participants resisted identity reconstruction through English by stating that they would prefer to abide by their L1 identity:

Interviewee 8. I haven't changed because I want to adjust myself to Islam and its rules not with the rules of the language I'm learning or with the country that speaks that language.

Interviewee 26. I haven't changed because learning a language has nothing to do with changing one's behaviour and personality.

Subsequently, in response to the enquiry as to their motivation to learn English, these 'resisting' learners stated that they were simply instrumentally driven to acquire English and that they did not intend to integrate into the target culture. It is hypothesised that integrative motivation directs a learner into more investment into the TL which will, in turn, result in more acculturation into the target culture and will finally bring about more learning opportunities for the language learner. For instance, Ushioda and Dörnyei (2009) speculate that tendencies toward the target culture are mainly driven by integrative motivation. Nevertheless, defining learners in binary terms such as motivated vs. unmotivated runs the risk of being neglectful of a lot of insights into the concept 
of identity particularly from a poststructuralist perspective (see Norton, 2014). In addition, recent research shows that in the course of identity reconstruction in L2, learners are both integratively and instrumentally motivated and that those with both types of motivation have a distinct advantage over those with only instrumental motivation (Tarhan \& Balban, 2014).

\section{Feelings toward Identity Reconstruction}

The next interview question dealt with the feelings that the participants had toward the impact, if any, that English has left on their identity perception (Question \#5). The results showed that 40 participants (90\%) believed that they felt or would feel pleased with the effect that the learning of English had or would have on their identity perception. The following quotes are indicative of this pleasure:

Interviewee 1. Learning English has influenced me a lot. It has caused me to listen to English songs, watch English films and series, use English as the language of my cell phone or any other electronic device I use, and so on.

Interviewee 11. Learning English causes our identity to be somewhat like that of English people and because English is an international language, then it's good.

Interviewee 17. By learning English your identity changes a bit. But everything depends on you. You may wish to learn the 'bad things' of English. Or you may like to learn the 'good things' of it.

Interviewee 28. I feel good because I think good changes have taken place since I started to learn English.

Interviewee 33. English has influenced me in a positive way. I pay attention to other cultures now, especially the English culture. Now I think I've got rid of monotony [in my life].

These quotes are also indicative of the fluctuating nature of motivation, being simultaneously both integrative and instrumental. To summarise, the majority of the interviewees did view the learning of English as leaving a positive impact on their identities as reconstructed in the L2. However, as predicted, some opposing voices were raised as follows:

Interviewee 8. It's good that I don't see English as influencing my origins. I'm Iranian and I'm still proud of that.

Interviewee 26. Identity isn't related to learning a language. It's related to the values and norms we have.

Interviewee 32. It'll be really bad if somebody changes their identity 
because of learning English because it'll cause them to look as if they're from another part of the world.

Interviewee 40. I don't want English to affect me because English people don't care about hijab and they dress inappropriately. But I'm a Muslim and an Iranian. I care about the way I get dressed and we observe Islamic regulations in all aspects.

The interviewees' emphasis on religion emanates from the fact that religion is a key shared social identity marker, one that designates not only one's way of life but also his/her kind of person (Downes, 2011).

\section{Identity Reconstruction: (Dis)advantages}

Developing from the previous question, the next interview question examined whether the impact of English on the language learner is positive or negative regardless of whether it has or has not affected the participants' identity perception (Question \#7). The results for this question show that 30 participants viewed this impact as positive, two participants as negative, and 11 participants with mixed feelings. Finally, two participants did not confirm any effect as a result of the learning of English.

Interviewee 1. This effect is good because English is accepted as an international language.

Interviewee 12. Language is like a key that opens new doors to how other people live and this causes the learner to look differently at his/her surroundings.

Interviewee 35. We can get familiar with other cultures when we learn other languages and, in this way, we will be personally mature.

Interviewee 37. The effect of English on our identity can be both good and bad. It depends. If we think of cultural aggression, then it's bad; but if we consider the good aspects of their culture, then it's good.

\section{Peers' and Parents' Views}

Defining identity at the interpersonal level, Roth (2010) states that, identity is 'who we are for ourselves and who we are in relation to others' (p. 116). As language learning and identity reconstruction are social endeavours, taking into account the role that other individuals such as learners' parents and classmates play in this process sounds quite justified. Therefore, to ensure the continuity of the interview questions, the participants were asked to voice their 
views regarding their peers' and parents' beliefs about identity reconstruction in the L2 (Question \#8).

The findings suggested that 36 participants believed that their parents and peers would welcome identity reconstruction while five participants predicted that peers' and parents' beliefs would be negative; three participants stated that their peers' and parents' viewpoints might fluctuate between contradictory, mixed feelings, depending on the circumstances and finally one participant had no idea on this issue. Parents' viewpoints are important simply because parents influence their children, impact their worldviews, are in constant contact with them and direct their children's learning path socioeconomically, affectively and emotionally. Some outstanding quotes are as follows:

Interviewee 2. Language learners' parents will see that their children can speak a language other than their own and this will help them make progress. This is why parents view this effect as positive.

Interviewee 8. My parents think of the effect of English as positive because they believe that if I learn English completely I'll get a good job in the future.

Interviewee 44. Their [parents'] opinion is positive in this regard because they believe that by learning another language we become able to understand other cultures.

One interviewee, nonetheless, believed that his parents and friends disapprove of the fact that English might influence learners' identity and culture and regard it as negative:

Interviewee 43. My parents think every language carries with itself the culture of the people who speak it. They just don't like this.

\section{Influential Factors}

The interviewees were also enquired regarding the factors that influenced their identity reformation as they set out to learn English (Question \#6). The participants' responses pointed to two major factors: a) media and the press (e.g., Internet, movies, textbooks, games, etc.) and b) the culture of Englishspeaking countries (e.g., communication with NSs of English by traveling to English-speaking countries). This part produced quotes like the following:

Interviewee 13. The media are the most influential means of communication. They transfer big quantities of sound, pictures and films so quickly.

Interviewee 18. Movies and clips contain many words that I don't know. This makes me look those words up in the dictionary and, in this way, I learn more about English language and culture. 
Interviewee 29. The Internet is very influential because it's so attractive to so many people because by using the Internet people can easily spread their own identity and influence our identity.

\section{Conclusion}

The participants' strong inclination to identify and, therefore, to integrate with the English culture can be construed as their viewing English as a tool with which to mark their identity. Some researchers attribute EFL learners' openness to a fresh identity perception to be the result of starting to learn English at a young age when learners' cultural identity has not yet been firmly established (see, e.g., Yihong, Zhao, Ying, \& Yan, 2007). This conclusion is also defendable here since almost all the interviewees reported that they had started to learn English in childhood. Besides, it might be indicative of their perception of the issue of 'ownership' of English. In this regard, these learners might have viewed the TL community as the 'norm', and NSs as the only legitimate 'owners' of English to be followed by 'outsiders', that is to say by 'foreign' language learners. As Norton (1997) pointed out, such a stance, although tentative and therefore in need of further research, demonstrates the participants' perception of English as belonging to its NSs and not to whoever speaks it. If this speculative conclusion proves correct, then it leads the discussion to the significant issue of native-speakerism defined as 'the over-representation of the "native-speaker" (NS) point of view at the expense of the "non-native-speaker" (NNS) one' (Waters, 2007, p. 281). Finally, it might come as a surprise to the participants to know that the issue of the native-speaker ownership of English has been seriously challenged (see, e.g., Norton, 1997; Widddowson, 1994).

The above speculation leads the discussion into the highly debated issue of the three circles of English (i.e., Inner, Outer and Expanding Circles; see Crystal, 2003; Kachru, 1985a, 1992). In conclusion, while the concept of 'nativespeakerism' has recently been seriously challenged by a myriad of scholars (e.g., Cook, 1999; Holliday, 2009; Jenkins, 2006; Kim, 2011; Lurda, 2009; Widdowson, 1994; Zhang, 2010, to name but a few), it is still prevailing among both language learners (e.g., Zacharias, 2012; Zhang, 2010) and teachers (e.g., Kim, 2011; Pavlenko, 2003), with the results of the current study lending more credence to previous findings. The issue of 'native-speakerism' brings us to another major concept in recent lines of research and theory: the Other. Following $\mathrm{Ku}-$ maravadivelu (2006), this is normally thought to be the result of the process of 'marginalisation'. Therefore, it is likely that the participants view themselves as outsiders to the domain of English and attempt to identify with the TL norms to 
mitigate this sense of outsiderness. The conclusion is that EFL learners, Zacharias (2012) pointed out, view their non-nativeness as a disadvantage to their language learning task/status. Over four decades ago, Scoon (1971) hypothesised that the desire to integrate with the foreign culture correlates positively with one's success in language learning.

By extension, such an assumption applies here where Iranian EFL learners were found to hold remarkably positive attitudes toward the impact that learning English has on their identity construction. According to Scoon (1971), this can act as a strong motivator and a major predictor of success in language acquisition. In practical terms, this can be deemed a latent opportunity for language teachers to take full advantage of in language pedagogy. This necessitates an acknowledgement and understanding of learners' multiple identities in the classroom on the part of teachers (see Norton, 1997). It was, consequently, the purpose of the current study to delve into language learners' perceptions of identity and identity reconstruction. Similarly, Ushioda (2009) asserts that this can be carried out through pedagogical practices that encourage students' multiple identities and foster autonomy among them. Ellis (2012) posited that the underlying assumption of all perspectives of identity is the view that language and the broader social world are inextricably associated and that the dominant power relationships must be addressed if language learning is to be promoted.

This study also has implications for critical pedagogy. Although it is commonly assumed that positive attitudes toward the TL and culture are conducive to language acquisition, 'blind imitation' is likely to turn out to be an impediment to the absorption of the target culture and to integration with the TL community. This is not advantageous. However, the possibly inherent danger in such views is the fact that EFL learners might view their NNS status as a drawback to language acquisition instead of regarding it as a resource for negotiating their non-native identity. Previous research bears testimony to this conclusion (see, e.g., Zacharias, 2012). Students are also to be made aware of the truth behind every language practice and of the fact that no practice, whatsoever, is free of power. Zacharias' (2012) solution is as follows: 'it is important for pre-service teacher education programs to introduce and integrate critical pedagogy, focusing on second language identities, nonnativeness, multicompetence, and multilingualism in their programs and/or existing courses' (p. 242). In a similar vein, Norton (1997) rightly formulated her Social Identity Theory on the basis of three assumptions, one of which is the view that, in order for the learners to promote language learning, they should develop an awareness of the right to speak up in the face of the predominant, overt or covert, power relations inherent in interactions. Language is not neutral, and relationships 
are heavily power-laden. Put differently, EFL learners, who are potential future EFL teachers, are to be empowered so that they assert, and even to take pride in, their NNS identity. As such, the study findings might be of concern to needs analyses as Li and Simpson (2013) highlighted.

In contrast, since it is hypothesised that one's identity is shaped and reshaped in interaction with others, and not in isolation (Blackburn, 2000), Iranian EFL learners' positive attitudes toward identity reconstruction in L2 can arguably be seen as a window of opportunity to language learning experience and access. Thus, teachers are supposed to capitalise on these remarkably positive attitudes as resources to foster acculturation capacities and learning capabilities for future interactions between EFL learners (i.e., NNSs) and NSs. An efficient path to take in language education programs can be a middle one in which the focus is on both integration/socialisation into the TL community and acknowledgement of its norms and appreciation of NNS' status as successful language users, not as failed language learners. In fact, as Hahn (2001) argued, 'Language learning does not have to imply a choice between one's own native identity and a foreign identity' (p. 262).

A further implication arising from the current study is the need for teachers to acknowledge their learners' multiple, shifting and wide-ranging identities, as opposed to the single-component view of identity. As Norton (2009) asserted, 'Each of us performs a repertoire of identities that are constantly shifting, and that we negotiate and renegotiate according to the circumstances' (p. 348). Teachers should take into account the fact that language learners are not merely learners. Rather, they might be workers, immigrants, parents, and even student teachers. By doing so, teachers recognise and acknowledge different versions of the same learners, thus allowing them to create and recreate themselves in the TL on their own. This is what Paulston (1978) called for, finding it 'reprehensible' to deny the learners the right to choose between the target and first culture. A final implication is the possibility to use the findings in carrying out needs analysis (Li \& Simpson, 2013).

The major limitation of the study is concerned with its sampling procedure. Data gathered from participants who are chosen by means of convenience sampling are likely to be biased and therefore should not be construed as being representative of the whole population (see Mackey \& Gass, 2005). Further, the findings should be substantiated with more triangulated data.

Note. An earlier version of this paper was presented under the title, 'Language learning, language learners and identity (re)construction: An investigation into an EFL context' at The $13^{\text {th }}$ TELLSI International Conference held at Lorestan University, Iran on November 17-19, 2015. 


\section{References}

Barnawi, O. Z. (2009). The construction of identity in L2 academic classroom community: A small scale study of two Saudi MA in TESOL students at North American university. Journal of Language and Linguistic Studies (JLLS), 5(2), 62-84.

Blackburn, L. A. (2000). The development of sociolinguistic meanings: The worldview of a deaf child within his home environment. In M. Metzger (Ed.), Bilingualism and identity in deaf communities (pp. 219-254). Washington, DC: Gallaudet University Press.

Burr, V. (2006). An introduction to social constructionism. London, UK: Routledge.

Cook, V. (1999). Going beyond the native speaker in language teaching. TESOL Quarterly, 33(2), 185209.

Crystal, D. (2003). English as a global language. New York, NY: Cambridge University Press.

Davies, A. (2007). An introduction to applied linguistics: From practice to theory (2nd ed.). Edinburgh, UK: Edinburgh University Press.

Day, E. M. (2002). Identity and the young English language learner. Clevedon, UK: Multilingual Matters. Deters, P. (2011). Identity, agency and the acquisition of professional language and culture. London, UK: Continuum International Publishing Group.

Downes, W. (2011). Language and religion: A journey into the human mind. Cambridge, UK: Cambridge University Press.

Ebtekar, P. (2012). Whose voice is telling the story? An Iranian immigrant woman's language learning experiences. TESOL in Context, Special Edition S3: November 2012. Retrieved from http://www.tesol. org.au/files/files/269_parisa_ebtekar.pdf

Edwards, J. (2009). Language and identity: An introduction. Cambridge, UK: Cambridge University Press.

Ellis, R. (2012). The study of second language acquisition. Oxford, UK: Oxford University Press.

Hahn, A. (2001). The "foreign" in foreign language education. In B. Johnston \& S. Irujo (Eds.), Research and practice in language teacher education: Voices from the field (pp. 257-267). Minneapolis, MN: Center for Advanced Research on Language Acquisition.

Holliday, A. (2009). English as a lingua franca, 'non-native speakers' and cosmopolitan realities. In F. Sharifian (Ed.), English as an international language (pp. 21-33). Bristol, UK: Multilingual Matters.

Huang, W. (2011). The EFL learner identity development: A perspective of metaphor. International Journal of Innovative Interdisciplinary Research, 1, 1-13.

Jenkins, J. (2006). Current perspectives on teaching World Englishes and English as a lingua franca. TESOL Quarterly, 40(1), 157-181.

Johnson, K., \& Johnson, H. (Eds.). (1999). Encyclopaedic dictionary of applied linguistics. Oxford, UK: Blackwell Publishing.

Johnstone, B. (2008). Discourse analysis (2nd ed.). Maiden, MA: Blackwell Publishing.

Joseph, J. E. (2009). Identity and language. In J. L. Mey (Ed.), Concise encyclopaedia of pragmatics (pp. 345-351). Oxford, UK: Elsevier Ltd. 
Kabuto, B. (2011). Becoming biliterate: Identity, ideology, and learning to read and write in two languages.

New York, NY: Routledge.

Kachru, B. B. (1985a). Standards, codification and sociolinguistic realism: The English language in the outer circle. In R. Quirk \& H. G. Widdowson (Eds.), English in the world: Teaching and learning the language and literatures (pp. 11-30). Cambridge, UK: Cambridge University Press.

Kachru, B. B. (1992a). The second diaspora of English. In T. W. Machan \& C. T. Scott (Eds.), English in its social contexts: Essays in historical sociolinguistics (pp. 230-252). New York, NY: Oxford University Press. Kim, H. (2011). Native speakerism affecting nonnative English teachers' identity formation: A critical perspective. English Teaching, 66(4), 53-71.

Kinginger, C. (2004). Alice doesn't live here anymore: Foreign language learning and identity reconstruction. In A. Pavlenko \& A. Blackledge (Eds.), Negotiation of identities in multilingual contexts (pp. 219-242). Clevedon, UK: Multilingual Matters.

Kumaravadivelu, B. (2006). Understanding language teaching: From method to postmethod. New Jersey, NJ: Lawrence Erlbaum Associates.

Larsen-Freeman, D., \& Cameron, L. (2007). Complex systems and applied linguistics. Oxford, UK: Oxford University Press.

Lazzaro-Salazar, M. V. (2013). Diving into the depths of identity construction and motivation of a foreign language learner. Argentinian Journal of Applied Linguistics (AJAL), 1(1), 6-23.

Lefkowitz, N., \& Hedgcock, J. (2006). Sound effects: Social pressure and identity negotiation in the Spanish language classroom. Applied Language Learning, 16(1), 17-42.

Li, L., \& Simpson, R. (2013). Telling tales: Discourse narratives of ESOL migrant identities. NovitasROYAL (Research on Youth and Language), 7(1), 1-16.

Lurda, E. (2009). Attitudes towards English as an international language: The pervasiveness of native models among L2 users and teachers. In F. Sharifian (Ed.), English as an international language (pp. 119-134). Bristol, UK: Multilingual Matters.

Mackey, A., \& Gass, S. M. (2005). Second language research. New Jersey, NJ: Lawrence Erlbaum Associates.

Morita, N. (2004). Negotiating participation and identity in second language academic communities. TESOL Quarterly, 38(4), 573-603.

Nabavi, M. (2010). Constructing the 'citizen' in citizenship education. Canadian Journal for New Scholars in Education, 3(1), 1-10.

Norton, B. (1995). Social identity, investment, and language learning. TESOL Quarterly, 29(1), 9-31.

Norton, B. (1997). Language, identity, and the ownership of English. TESOL Quarterly, 31(3), 409-429.

Norton, B. (2009). Identity: Second language. In J. L. Mey (Ed.), Concise encyclopedia of pragmatics (pp. 358-364). Oxford, UK: Elsevier.

Norton, B. (2011). Identity. In J. Simpson (Ed.), The Routledge handbook of applied linguistics (pp. 318330). London, UK: Routledge.

Norton, B. (2013). Identity and language learning: Extending the conversation. Bristol, UK: Multilingual Matters. 
Norton, B. (2014). Identity and poststructuralist theory in SLA. In S. Mercer \& M Williams (Eds.), Multiple perspectives on the self in SLA (pp. 59-74). Bristol, UK: Multilingual Matters.

Norton, B., \& McKinney, C. (2011). An identity approach to second language acquisition. In D. Atkinson (Ed.), Alternative approaches to second language acquisition (pp. 73-94). London, UK: Routledge.

Ortega, L. (2009). Understanding second language acquisition. London, UK: Hodder Education.

Paulston, C. B. (1978). Biculturalism: Some reflections and speculations. TESOL Quarterly, 12(4), $369-380$.

Pavlenko, A. (2003). "I never knew I was a bilingual": Reimagining teacher identities in TESOL. Journal of Language, Identity, and Education, 2(4), 251-268.

Rich, S., \& Troudi, S. (2006). Hard times: Arab TESOL students' experiences of racialization and othering in the United Kingdom. TESOL Quarterly, 40(3), 615-627.

Ritzau, U. (2015). Self-positioning through beginners' foreign language. International Journal of Applied Linguistics, 25(1), 105-126. doi: 10.1111/ijal.12053

Roth, W. (2010). Language, learning, context. New York, NY: Routledge.

Sato, T. (2014). The effects of study abroad on second language identities and language learning. Turkish Online Journal of Qualitative Inquiry, 5(3), 28-41.

Saville-Troike, M. (2006). Introducing second language acquisition. Cambridge, UK: Cambridge University Press

Schecter, S. R., \& Bayley, R. (1997). Language socialization practices and cultural identity: Case studies of Mexican-descent families in California and Texas. TESOL Quarterly, 31(3), 513-541.

Scoon, A. R. (1971). Affective influences on English language learning among Indian students. TESOL Quarterly, 5(4), 285-292.

Tamimi Sad, S. H., \& Modirkhamene, S. (2015). Examining Acculturation Model in an EFL context: Learners' attitudes towards target language accent vs. L1 accent. GEMA Online Journal of Language Studies, 15(1), 25-38. Retrieved from http://journalarticle.ukm.my/8257/1/5373-22053-1-PB_(1).pdf

Tarhan, H., \& Balban, S. (2014). Motivation, learner identity and language learning. International Journal on New Trends in Education and Their Implications, 5(1), 183-197.

Trappes-Lomax, H. (2004). Discourse analysis. In A. Davies \& C. Elder (Eds.), The handbook of applied linguistics (pp. 133-164). Malden, MA: Blackwell Publishing.

Ushioda, E. (2009). A person-in-context relational view of emergent motivation, self and identity. In Z. Dörnyei \& E. Ushioda (Eds.), Motivation, language identity and the L2 self (pp. 215-228). Bristol, UK: Multilingual Matters.

Ushioda, E., \& Dörnyei, Z. (2009). Motivation, language identities and the L2 Self: A theoretical Overview. In Z. Dörnyei \& E. Ushioda (Eds.), Motivation, language identity and the L2 self (pp. 1-8). Bristol, UK: Multilingual Matters.

Wang, Y., \& Phillion, J. (2011). Hui Students' identity construction in eastern China: A postcolonial critique. Turkish Online Journal of Qualitative Inquiry, 2(4), 39-51.

Waters, A. (2007). Native-speakerism in ELT: Plus ça change...? System, 35(3), 281-292.

Widdowson, H. (1994). The ownership of English. TESOL Quarterly, 28(2), 377-389. 
Wortham, S. (2008). Shifting identities in the classroom. In C. R. Caldas-Coulthard \& R. Iedema (Eds.), Identity trouble: Critical discourse and contested identities (pp. 205-228). New York, NY: Palgrave Macmillan.

Yihong, G., Zhao, Y., Ying, C., \& Yan, Z. (2007). Relationship between English learning motivation types and self-identity changes among Chinese students. TESOL Quarterly, 41(1), 133-155.

Zacharias, N. T. (2012). EFL students' understanding of their multilingual English identities. Electronic Journal of Foreign Language Teaching, 9(2), 233-244.

Zhang, Q. (2010). Attitudes beyond the inner circle: Investigating Hong Kong students' attitudes towards English accents. Unpublished doctoral dissertation. Newcastle University, United Kingdom.

\section{Biographical note}

Seyyed Hatam Tamimi SA'd holds a MA in English Language Teaching from Urmia University, Iran and is currently an English teacher in Iran Language Institute (ILI), Iran. He serves as a reviewer and editorial board member for several journals including Journal of Sociolinguistics, British Journal of Educational Technology (BJET), British Educational Research Journal (BERJ), TESL-EJ and The Canadian Journal for New Scholars in Education (CJNSE). His interest lies in identity, acquisitional and interlanguage pragmatics. 


\section{Appendix}

\section{Focus group interview}

\section{Demographic Information}

Age: ..... Mother tongue: ..... Ethnic background: ..... Sex: Male / Female How long have you been learning English at language institute(s): ... Years

\section{Interview Questions}

1. Define identity in your own words.

2. Is it important for a person to have a specific identity (i.e., to be Iranian, American, English, African, etc.)? why or why not? Please explain.

3. In your opinion, has the learning of English affected your attitude toward your identity? If yes, then do you view this effect as positive or negative? Please elaborate.

4. What viewpoint did you hold toward your identity as Iranian before you started to learn English? Has your identity changed since you started to learn English? If so, then in what way has your identity changed?

5. How do you feel now that English has or has not impacted on your identity? Do you feel positive or negative? Please explain.

6. What causes the English language to impact a learner's identity? Please elaborate.

7. In your viewpoint, is the impact of learning English, if any, on the learner's identity positive or negative? Why? Please explain.

8. Do your parents and friends view the impact of learning English, if any, on the learner's identity as positive or negative? Why? Please explain. 